\title{
The Mystery of "Collaboration" in Henry James
}

\author{
James Lello
}

check for updates

Citation: Lello, James. 2021. The Mystery of "Collaboration" in Henry James. Humanities 10: 69. https://doi.org/10.3390/h10020069

Received: 12 January 2021

Accepted: 2 April 2021

Published: 13 April 2021

Publisher's Note: MDPI stays neutral with regard to jurisdictional claims in published maps and institutional affiliations.

Copyright: (C) 2021 by the author. Licensee MDPI, Basel, Switzerland. This article is an open access article distributed under the terms and conditions of the Creative Commons Attribution (CC BY) license (https:/ / creativecommons.org/licenses/by/ $4.0 /)$.
St Catharine's College, University of Cambridge, Cambridge CB2 1RL, UK; jaehl2@cam.ac.uk

\begin{abstract}
This article argues for the importance of collaboration as a species of literary relation in Henry James's work. Collaboration was increasingly popular towards the end of the nineteenth century, and yet, James's interest in and occasional practice of this compositional mode has been largely overlooked. This is partly due to James's own ambivalent and contested relationship with multiple authorship, most obviously in his contribution to The Whole Family. However, James's frequent identification of collaboration as a "mystery" indicates the extent to which it exerted a considerable influence over his imagination and thinking, and its association with some of his most formative moments of novelistic and vocational self-awareness. "Collaboration" is also a literary subject in its own right, most obviously in James's 1892 story of that name, and the depiction of the practice as a unifying, if occasionally divisive, ideal offers a complex and often enigmatic vision of sociable reciprocity.
\end{abstract}

Keywords: Henry James (1843-1916); relations; collaboration; tone

Few of Henry James's critical statements can be as familiar as that found in the 1907 Preface to the revised edition of Roderick Hudson:

Really, universally, relations stop nowhere, and the exquisite problem of the artist is eternally but to draw, by a geometry of his own, the circle within which they shall happily appear to do so. (James 1984a, p. 1041)

James, we may recall, is answering his own question regarding where "for the complete expression of one's subject" the possible relations in a given work of art may cease, where a novelist's material stops being "indispensable" and where it starts becoming merely arbitrary or superfluous (James 1984a, pp. 1040-41). Totality need not presuppose wholeness, since a "complete expression" is by no means achieved by trying to take everything in. Stopping art can itself be an art, as discovered by the painter of La Belle Noiseuse in Balzac's 1831 story "The Unknown Masterpiece", where everything is ruined by the final touch to a painting which it did not need. Yet, a geometry of one's own is something of an oxymoron, the laws of geometry being as universal as the relations they putatively delimit. Rather than incurring some kind of category error, this might disavow the perfected circumscription to which the sentence professes. ${ }^{1}$ This circle never "really" limits these relations anyway but must itself be drawn "eternally", as though participating in the very problem it supposedly resolves. "Our life", writes Emerson in his 1841 essay "Circles", "is an apprenticeship to the truth, that around every circle another can be drawn" (Emerson 1883, p. 282).

Much of the force of James's sentence derives from the way it sounds like a proposition and yet resists paraphrase, from its calibrated poise between authoritativeness and ambiguity, sententiousness and speculation. This is especially evident once it is considered from the perspective of tone. If we pause after "Really", as though enacting a momentary throat-clearing before the clause's beginning ("universally"), the sentence carries the moralizing tone redolent of the universally acknowledged truth of Pride and Prejudice (Johnston 2018, p. 211). Heard another way, we might pause a second time after "universally", distributing equal emphasis to both adverbs (as though universality might

\footnotetext{
1 This point is made by Freya Johnston (Johnston 2018, p. 226).
} 
denote, or at least convey an extension of, an existing state of affairs). "Really" foregrounds this double sense, since it might function as either a discourse marker or a philosophical denotation; it might convey a variety of conversational implications, ranging from an argumentative mustering of assertion ("indeed" or "in truth") to a sociable idiom of heightened sincerity or from a tone of confiding advice to pontificating conclusiveness (as in "all things considered" or "at the end of the day"). Heard more literally, it resembles a metaphysical claim: "really, all relations imply a whole to which the terms contribute and by which the terms are qualified" (Bradley 1893, p. 581). The emphasis on "appear" invites further ramifications of sense: if the circle circumscribes proliferating relations, it only gives the appearance of doing so-not because its finitude is fraudulent, but because the circle (itself is a metaphor of endlessness) is inseparable from the mimetic achievement of fiction itself. Others might hear this stress more literally, so that "appear" conveys the geometry within which relations do appear to stop, rather than successfully depicting their cessation (McWhirter 1995, p. 11). "[A]ppear" would then suggest a manifestation rather than a mimesis (although if in "reality" or the "universe" such relations do not stop, it is perhaps hard to see how relations can be anything other than mimetic). The tension between these two understandings of "appear" as either a representation or realization is characteristic of the variety of voices audible in the Prefaces, where James's tone is so frequently "apologetic" and "assertive" (Wilson 2017, p. 256). Here, the difference between an emphatic assertion and a claim about the reality of universals, between a sociable idiom and philosophical categorization, will largely depend upon the intonation with which the line is read.

Relations, at least in James's most famous articulation of the concept, pose an exquisite problem for the artist, a problem whose expression itself ramifies into multiple forms and which requires a great deal of art to either resolve or reveal. Yet, how much greater, how much more exquisite, will this problem be when such relations arise not just from a single author's work but multiple? About the same time as the Roderick Hudson Preface, James contributed to The Whole Family, a "novel by twelve authors" serialized in 1906-1907 for Harper's Bazar and published in book form the following year. Each of the contributors were invited to write a chapter on a member of the eponymous family, and each of these chapters variously explores the main shared plot point of the novel: the marriage of the daughter Peggy. James was tasked with "The Married Son", Charles Edward, an artist at odds with the rest of his family and who divulges his feelings and frustrations in a private journal-in which form James's chapter appears. Amongst Charles Edward's various reflections on art, the problem of "relations" appears in prototypical form:

As I read over what I have written the aspects of our situation multiply so in fact that I note again how one has only to look at any human thing very straight (that is with the minimum of intelligence) to see it shine out in as many aspects as the hues of the prism; or place itself, in other words, in relations that positively stop nowhere. I've often thought I should like some day to write a novel; but what would become of me in that case-delivered over, I mean, before my subject, to my extravagant sense that everything is a part of something else? When you paint a picture with a brush and pigments, that is on a single plane, it can stop at your gilt frame; but when you paint one with a pen and words, that is in all the dimensions, how are you to stop? (James et al. 2001, p. 167)

Even recognizing the ironic aggrandizement of Charles Edward's aesthetic excesses, it is hard not to hear an elective affinity between James and his imagined artist, as though James were ventriloquizing his own ambivalences about collaboration as a practicable ground for literary relations in both a conceptual and familial sense. Immediately after this passage, Charles Edward cites his wife's dictum "Stopping, that's art", and goes on to compare artists with the drivers of "trolley-cars, in New York, who, by some divine instinct, recognize in the forest of pillars and posts the white-striped columns at which they may pull up" (James et al. 2001, pp. 167-68). The metaphor recalls perhaps Elizabeth Jordan's chapter on Peggy's sister, "The School Girl”, where the trolley-car evokes her desire to 
leave the family behind altogether, and go "as far away from home as our nickels would take us, and not hurry back" (James et al. 2001, p. 106). As a metaphor for collaboration, the trolley-car not only conveys the "divine instinct" of knowing where to stop but, also, the theoretically irreversible nature of the project's continuity: "each author in turn [was envisaged as] taking up and carrying on the tale from the point where the last writer had dropped it" (Jordan 1938, p. 258). Yet, as James complained to Elizabeth Jordan, who was also the volume's editor, the smooth transition from one chapter to the next was undermined by the failure of his fellow contributors to grasp his low-hanging fruit: "I left them these Values, fairly dangling there, to my best ability, as it were, for my successors to catch at. But alas they haven't" (James and Howells 1958, p. 51). ${ }^{2}$ The collaboration might have enabled an improvisatory freedom, but in reality it encouraged contingency or arbitrariness. The requisite art of arrest not only applies to the prismatic hues of James's fellow contributions, but also to his own creative instincts: after writing "The Married Son", he wrote to Jordan (18 February 1907) that "One of course can't do such a piece at all without one's imagination projecting a coherent sequel and consequence (to one's own Part-as if one were to do it all one's self)" (James and Howells 1958, p. 33). ${ }^{3}$ As Philip Horne concludes: the project "was doomed from the start to fragmentation and collapse, for the stupidities and treacheries and incapacities and trivialities which made it like all too many other families, and other fictions" (Horne 1987, n.p.).

Facts of chronology reinforce the connection between the famous sentence from the Preface to Roderick Hudson and this experimentation with multiple authorship: James began editing his chapter for The Whole Family between 25 January and March 1907 (having started it at the end of the previous year), and he was revising Roderick Hudson around February/March 1906. The first two editions of the New York Edition arrived on his doorstep on New Year's Eve, to his considerable delight (McWhirter 1995, p. 79). ${ }^{4}$ Moreover, as Philip Horne notes, Charles Edward is himself "conceived as an up-to-date Roderick Hudson, desperate to escape philistine Eastridge as Roderick is Northampton, Massachusetts, and likewise ruthlessly satirical" (Horne 1987, n.p.). Charles Edward's rereading of "what I have written" in his diary echoes James's rereading of his works for the New York Edition, and he also entertains the possibility of writing "a novel". Furthermore, Charles Edward's question ("how are you to stop?") recalls the invocation of the "presumability somewhere of a convenient, of a visibly-appointed stopping-place" in the Roderick Hudson Preface, though James swiftly dismisses this presumability as ultimately undesirable: art would be easy indeed should it automatically provide such "conveniences" and "simplifications" (James 1984a, p. 1041).

What follows develops the idea that the famous articulation of relations emerges from James's experiments with multiple authorship and that his theoretical speculation in the Preface is grounded in a long-standing interest in the problems attending this historically circumscribed practice. It falls into four parts: the first outlines some of the reasons why collaboration has been overlooked in James's work and suggests that, even when collaboration appears to confirm his supposedly appropriative tendencies, it

2 James's chapter ends by setting up some confrontation between Charles Edward and Harry Goward, where the former would outline the family position: "I tried to suggest some values for this \& to leave them suggested: his confrontation with the kidnapped \& 'compromised' youth in the Park as a Value, his meeting [,] his 'having it out,' with Eliza \&, as it were disposal of her, as a Value" (James and Howells 1958, p. 51).

3 After reading Mary E. Wilkins Freeman's contribution, "The Aunt", James similarly complains to Jordan (11 January 1907) that "My difficulty is only, alas, that I verily tend to burst my bonds or my frame; to blow, that is, the roof off the house. But to prevent this uneasy consciousness I should have had to do them all myself!" (James and Howells 1958, p. 44).

4 Horne notes that James began writing his chapter in November 1906 (Horne 1987, n.p.), though because he only read Jordan's contribution on the 27 November 1906, he might only have begun his chapter soon after. As James writes to Jordan (16 October 1906), he felt he could not start before reading what had gone before his chapter: "I incline meanwhile, I may also say, to 'close' with you on the question of the Married Son; but can't be sure I see my way until I have read all of what leads up to him" (James and Howells 1958, p. 41). Alfred Bendixen notes the difficulty in "Dating James's entry into the family" and that "the first mention of The Whole Family in James's letters in the Jordan Papers does not occur until a letter dated 16 October 1906" and that, whilst the letters dated 17, 20 and 27 July 1906 refer to the articles he was writing for the Bazar, James does not mention the collaborative venture. James's name does not appear on the early list of contributors (probably drawn up in June 1906), and Bendixen thus concludes that James was amongst the last of authors to join the project (and most likely replaced Henry B. Fuller, who was listed as writing the chapter on the married son) (James et al. 2001, pp. xlii-xliii). 
also conveys a desire for beneficence and solicitude. The second part proposes that the "mystery" of collaboration accounts for James's fascination with an elusive compositional mode, which nevertheless exerted considerable force upon his imagination. For James, the "mystery" emerges initially from the cosmopolitan and sociable ideals associated with French writers; the third section also shows that such mystery is not just conditioned by, but potentially overcomes, any national distinctions, referring, in particular, to James's 1892 story, "Collaboration". The essay concludes by indicating some ways of exploring collaboration further, with particular reference to James's later fiction.

\section{Interfusions}

The inverted commas over "Collaboration" in the title to this essay may look like raised eyebrows. ${ }^{5}$ Raised if only because the cult of the master has been largely responsible for a conception of James as profoundly uncollaborative, a conception which The Whole Family only reinforces. On the few occasions where readers raise the possibility of multiple authorship in his work, it rarely represents a moment of approbation; one anonymous reviewer of The Wings of the Dove for the London Daily Chronicle concluded James must be a "joint author" only because the "infinite complications of the mechanism" of his protagonists' minds exceeded the ratiocinative power of any single consciousness (Hayes 1996, p. 361). Even setting aside the échec of The Whole Family, the most cursory survey of James's collaborative ventures apparently confirms the difficulty of straightforwardly identifying him with this compositional practice. Whilst he put his name to "The Ghost", a play predominantly authored by Stephen Crane and performed at Brede Hill School-room in 1899 (1969, vol. 8, p. 177), the program remains all that is extant (Crane 1899), and the nature of the respective contributions is unclear. ${ }^{6}$ In a letter to James (22 January 1895), the composer Sir George Henschel asked him to write the libretto for an opera, but this was rejected: "Your flattering dream is beautiful—but, I fear, alas, delusive. When I say I 'fear' it, I mean I only too completely feel it" (James 1920, vol. 1, pp. 229-30). Part of the felt "delusion" is the result of James's avowed lack of musical proficiency ("I am unlyrical, unmusical, unrhythmical, unmanageable"), but he nevertheless agrees to "talk" of the idea with Henschel, if only because conversion facilitates a degree of freedom: "I will talk with you, with joy, of anything — will even play to myself that I have convictions I haven't, for that privilege" (James 1920, vol. 1, p. 230). Leon Edel speculates that James might have collaborated with Constance Fenimore Woolson (Edel 1962, p. 319), but as Adeline Tintner notes, we only have her "word for it in a letter that may represent simply wishful thinking on her part and/or placation on his" (Tintner 1983, p. 140). ${ }^{7}$ James's $^{\prime}$ collaborations might, at best, be limited to Alvin Langdon Coburn's frontispieces to the New York Edition, Joseph Pennell's illustrations, or the act of dictation: Edith Wharton consoled James's amanuensis, Theodora Bosanquet, by alluding to her "collaboration with one of the wisest \& noblest men that ever lived" (Anesko 2012, p. 64). Collaboration would appear to be a "mystery" if only for the simple reason that James never successfully achieved it.)

Even when James did occasionally express a desire to collaborate, it often seems inextricable from a practice of solitary creation, conforming perhaps to certain AngloAmerican ideals of masculinity and genius rather than mutual and reciprocal exchange. 8 The Whole Family provides an instance of the agency of a "lonely author" exercised over the "whole family" (Perosa 1978), and "bears witness to the magnanimous, wasteful vigour of James's unifying imagination" (Horne 1987, n.p.). The urge to collaborate often

5 This adapts a comment made by Geoffrey Hill (Hill 2008, p. 3).

6 As Crane wrote to H.B. Marriott-Watson on 15 November: "I have hit upon a plan of making the programmes choice by printing thereon a terrible list of authors of the comedy and to that end I have asked Henry James, Robert Barr, Joseph Conrad, A.E.W. Mason, H.G. Wells, Edwin Pugh, George Gissing, Rider Haggard and yourself to write a mere word—any word 'it', 'they', ' you' —any word and thus identity themselves with this crime" (Crane 1969, vol. 8, p. 835).

7 For Victoria Coulson, James's correspondence with Woolson itself demonstrates an "elusive pattern of conflict and collaboration; an ambivalent and inexplicit negotiation between social conservatives who tacitly colluded to resist the authority of heterosexual gender norms"; in this respect "their collaborative 'failures' function as ideological screens for their refusals' (Coulson 2007, pp. 97, 126).

8 For a challenge to this ideal, see Bette London (London 2002). 
derived from this urge to entirely rewrite an existing work. In a letter to Howard Sturgis on 23 November 1903, James expresses his regret not to have been more involved in the genesis of the 1904 novel Belchamber but urges him to "Start next year another book and let me anonymously collaborate" (1984c, vol. 4, p. 294). On 23 September 1902, James responds similarly to a letter by H.G. Wells regarding Elizabeth Stoddard's 1865 novel Two Men, which he reviewed when it came out as "almost brutally crude" (James 1984b, p. 615).

It is, the whole thing, stupendous, but do you know what the main effect of it was on my cheeky consciousness? To make me sigh, on some such occasion, to collaborate with you, to intervene in the interest of-well, I scarce know what to call it: I must wait to find the right name when we meet. You can so easily avenge yourself by collaborating with me! Our mixture would, I think, be effective. (James 1984c, vol. 4, p. 257)

James playfully implies that his wish to collaborate does not presume a reciprocity, inviting Wells's own agency. As in the Sturgis letter, there is also a sense that reading might always contain the possibility of collaboration, even if this collaboration is inevitably partial or one-sided..$^{9}$

Perhaps the most notorious instance of this appropriative tendency is James's editing his own brother's letters for the "Family Book" (23-24 September 1912) that was to become Notes of a Son and Brother. Writing to his nephew Harry, Henry James explains the 'revival of relation' felt when reading William's correspondence:

And when I laid hands upon the letters [...] I found myself again in such close relation with your Father, such a revival of relation as I hadn't known since his death, and which was a passion of tenderness for doing the best thing by him that the material allowed, and which I seemed to feel him in the room and at my elbow asking me for as I worked and as he listened. (James 1984c, vol. 4, p. 802)

The ethical implications of James's claimed continuity with historical experiences that he did not have might raise certain objections here, and critics have resisted the potential imposition such documentary access implies. ${ }^{10}$ When James apologizes to his nephew for these controversial edits, he claims: "I have to the last point the instinct and the sense for fusions and interrelations, for framing and encircling (as I think I have already called it) every part of my stuff in every other-and that makes a danger when the frame and circle play over too much upon the image" (James 1984c, vol. 4, p. 803). "Fusions and interrelations" intermingle in "interfusion", a word often used by James to convey a reconciliation of difference: the "conflict between idealism and realism" is "so harmoniously interfused" in Tintoretto's "Last Supper" that James "def[ies] the keenest critic to say where one begins and the other end"; of Venice in general, there is "nowhere" where "art and life seem as interfused and, as it were, consanguineous" (James 1909, p. 25). ${ }^{11}$ "Interfusion" conjures a powerfully Wordsworthian idiom, whilst consanguinity is also evoked in "The Prelude" (II: Schooltime), where Wordsworth describes how the "'infant Babe' is no outcast, bewildered and depressed", because

Along his infant veins are interfused

The gravitation and the filial bond

9 In his 1866 essay "The Novels of George Eliot", James suggests that telling a story invariably relies on the reader doing their "share", but he nevertheless retains authorial control: such a collaboration is only ever partial because the reader only does "half the labor" when they are made "well" by the author and, when made badly, does none at all (James 1984b, p. 922).

10 For Michael Millgate, the letter is "fully reflective of the characteristic imperiousness of [James's] irresistibly expansive imagination" (Millgate 1992, p. 96).

11 In his 1888 essay on Guy de Maupassant, James writes that "[e]very good story is of course both a picture and an idea, and the more they are interfused the better the problem is solved" (James 1984a, p. 537). In The Whole Family, familial "interfusion" thus reaches a state of crisis, as its protagonists seem to be occasionally aware. Charles Edward reflects on the eldest daughter Maria: "Deadly virtuous and deadly hard and deadly charmless [ ... ] how does Maria fit on, by consanguinity, to such amiable characters, such real social values, as Mother and me at all?" (James et al. 2001, p. 154). 
Of Nature that connect him with the world (Wordsworth 2008, pp. 338-39). ${ }^{12}$

"Interfusion" also allows us to see James's relationship with the past as more like an ongoing conversation than an instance of imperious acquisitiveness, as an extension of a kind of filial consanguinity embodied by the Goncourts. William's letters might thus convey the intimacy of mutual contact without the necessity of physical presence. ${ }^{13}$ As Tamara Follini suggests of the amendments for the "Family Book": "When James heard letters, he spoke back to them, he wrote back to them, in revisions which imagine an ideal mutuality, an enclosure of corresponding voices, a claim on an intimacy of relation and possession enacted in the spaces of silent-speaking words" (Follini 2003, n.p.).

In the 1912 essay "The Novel in The Ring and the Book", James describes his own engagement with the impressions conjured by the story that inspired Browning's poem as an "imaginative collaboration". James's reimagining of Browning's story contributes to the "vividest of all stories and one of the sharpest of all impressions", and in turn, yearns for "'something that will repay my fancy tenfold if I can but feel it" (James 1984b, p. 803). Whilst James is fully aware of the potential encroachment this rewriting might incur, that it might take liberty or "stray too far" (James 1984b, p. 810), he is also unable to stop himself imagining Caponsacchi as the work's "enveloping consciousness" or else a climactic "mutual confrontation" between Caponsacchi and the Pope: "Unless, unless, further and further, I see what I have at this late moment no right to" (James 1984b, p. 810). However, like the intimate mutuality implied by the edits to the "Family Book", James's essay might more generously be understood as extending the original creative act as a testimony to its author: "Browning works the whole thing over-the whole thing as originally given him — and we work him; helpfully, artfully, boldly, which is our whole blest basis" (James 1984b, p. 807). Such beneficence is captured by James's concluding image of Browning's "great generous wings" which remain "over us still" and which "shake down on us his blessing" (James 1984b, pp. 810, 811). Even at those moments when collaboration appears to be at its most acquisitive or imperiousness, James nevertheless emphasizes the reparative over interpellation, sociability over subjection. If James hopes that his reimagination of Browning is "at the worst a restless refinement of homage" (James 1984b, p. 810), we might add that it is, at best, a collaboration.

\section{2. "Always a Mystery"}

James's first recorded encounter with collaboration occurs in A Small Boy and Others, when his childhood friend and New York schoolmate, Louis De Coppet, made a notable offer of joint authorship:

He opened vistas, and I count ever as precious anyone, everyone, who betimes does that for the small straining vision; performing this office never so much, doubtless, as when, during that summer he invited me to collaborate with him in the production of a romance which il se fit fort to get printed, to get published, when success, or in other words completion, should crown our effort. Our effort, alas, failed of the crown, in spite of sundry solemn and mysterious meetingsso much devoted, I seem to remember, to the publishing question that others more fundamental dreadfully languished; leaving me convinced, however, that

12 See, also, Tintern Abbey, "Lines Written a Few Miles Above Tintern Abbey" (Wordsworth 2008, p. 134). My thanks to Adrian Poole for highlighting the Wordsworthian import of this word to me.

13 We might compare this with Sharon Cameron's suggestion that James would be "momentarily in collaboration" with Minnie Temple as he voices his thoughts about the reproduction of her letters (Cameron 1989, p. 155). James notes how "it was a miracle to me (and is still as I go on further) how the memories revived and pressed upon me, and how they keep a-doing of it in the 'letters' book" (James 1984c, vol. 4, p. 794). The phrase "keep a-doing of it" evokes a collaborative principle of continuity, and Herford notes that James found the expression especially memorable when responding to a letter from Thomas Sergeant Perry admiring one of his stories (Herford 2016, p. 268): “'Keep a doin' of it.' I have had nothing in a very long time please me so much as yr. expression—so full and so spontaneous—of confidence + sympathy" (James 2006, vol. 1, p. 91) For Herford, the phrase, which is either a citation from a letter or a colloquialism, implies that "the writing is sustained by a confidence in warm reciprocal interest: these are not things one can keep doing on one's own" (Herford 2016, p. 268). Like the phrase "getting on" in "Collaboration", "'keep a doin' of it" conveys a continuity and congruity that depends on good company. 
my friend would have got our fiction published if he could only have got it written.

(James 1913, pp. 34-35)

The scene represents one of the many recounted initiations, inductions and first beginnings that comprise James's autobiographical writings. ${ }^{14}$ The proposal "to collaborate" awakened James's own sense of artistic vocation: "there had been a mild magic in that breath, however scant, of another world" (James 1913, p. 36). However, curiously, this otherworldly intimation derives from the offer to write a romance that was never completed "in spite of sundry solemn and mysterious meetings" (James 1913, p. 35). James did not even demonstrate "the least "phenomenal' symptom" of the writerly gift that De Coppet so formatively "imputed" (James 1913, p. 35). Whilst this scene apparently confirmed the unpropitious status of this compositional practice (no collaborative work was ever actually produced), the influence of De Coppet's offer was, nevertheless, profound. James's interest in collaboration may have indeed been exacerbated by its lapsed fruition.

De Coppet was half-French on his father's side, and his invitation to collaborate was also an invitation into Europe and into French in particular. James's friend, "though theoretically American and domiciled, was naturally French, and so pressed further home to me that 'Sense of Europe' to which I feel that my very earliest consciousness waked" (James 1913, p. 34). This awakening is figured as a "toy hammer that drove in the very point of the golden nail" (James 1913, p. 35), and the golden nail metaphor, alluding to Solomon's building of the Temple (2 Chronicles 3:9), typically occurs in James's writing to convey a sense of self-advancement or transformative edification. ${ }^{15}$ This initiation into Europe also relied on the perception of speech and tone. James was struck by De Coppet's pronunciation of Ohio and Iowa, "which he rendered, as to their separate vowels, with a daintiness and a delicacy invidious and imperturbable, so that he might have been Chateaubriand declaiming Les Natchez at Madame Récamier's-O-ee-oh and Ee-o-wah" (James 1913, p. 33). ${ }^{16}$ Despite the attendant "serried circle of little staring and glaring New Yorkers", James insists those "were the right names-which we owed wholly to the French explorers and Jesuit Fathers; so much the worse for us if we vulgarly didn't know it" (James 1913, p. 33). As Oliver Herford suggests, the phrase "il se fit fort" ("which he was sure he would be able to get printed") offers an "invitation to the reader-aloud to collaborate in voicing the formula for Louis' confidence" (Herford 2016, p. 211), whilst the "wedge" that split James's national allegiance into "unequal halves" (James 1913, p. 35) recalls the claim in "The Speech of American Women" (1906-1907) that the "coherency of speech" is "the narrow end of the wedge they insert into our consciousness" (James 2004, p. 77), further alerting James to a consciousness of national differences (Herford 2016, p. 221). ${ }^{17}$ The fact that this awareness derived from an invitation to collaborate only reinforced James's nascent auditive intelligence, because this compositional practice itself evoked the idealized sociability, the soirées and salons, the conversation and cosmopolitanism, of France.

In his 1888 review of the Journal of Edmond and Jules de Goncourt, James reflected more explicitly on the enigma of multiple authorship, as well as its affiliation with France:

14 Emerson's tone was the "first glimmer of a sense that the human tone could, in that independent and original way, be interesting" (James 1914, p. 165), and the visit to the Galerie d'Apollon in the Louvre, aged thirteen, represented the "most appalling and yet most admirable nightmare of my life", whilst the notes sounded by his aunt when instructing her daughter to go to bed was "epoch-making" (James 1913, pp. 152, 277).

15 In The Sense of the Past, silver nails mark the turning points of Ralph Pendrel's life, "a change of attitude, a change of sensibility, as I must call it" (James 1917, pp. 307, 308, 310, 311, 214), a "clou d'argent of the very sharpest salience" (James 1917, p. 317). In The Ambassadors (James 1903a), perhaps James's most extensive account of the initiation of an American into the "Sense of Europe'", Lambert Strether is repeatedly pierced by Madame de Vionnet's "golden nail": when he asks her to refrain from asking her daughter her feelings about Chad Newsome, she says "“Thank you'" in a tone that "lingered with him", as though "she had driven in, by a single word, a little golden nail, the sharp intention of which he signally felt" and that returned to haunt him (James 1903a, pp. 197, 216).

16 For the significance of Chateaubriand's novel Les Natchez, see Herford (Herford 2016, p. 221). Madame Récamier (1777-1849) was a French socialite whose salon Chateaubriand frequented.

17 Oliver Herford views James's retrospective practice as itself "essentially sociable, occasional, and collaborative", revealing a "shareable acquaintance with the deceased, engaging readers on a ground of renewed retrospective appreciation, and helping to restage and perpetuate past associations, acquaintances, and habits" (Herford 2016, p. 14). 
"Collaboration" is always a mystery, and that of MM. de Goncourt was probably close beyond any other; but we have seen the process successful several times, so that the real wonder is not that in this case the parties to it should have been able to work together, to divide the task without dividing the effect, but rather that nature should have struck off a double copy of a rare original. An original is a conceivable thing, but a pair of originals who are original in exactly the same way is a phenomenon embodied so far as I know only in the authors of "Manette Salomon." (James 1984a, p. 411)

When James says that "Collaboration' is always a mystery", what does he mean? James might have been recalling those "mysterious meetings" with De Coppet, but unlike the Goncourts, the earlier mystery existed despite, rather than in service of, any collaborative venture (which, in any event, never materialized). More generally, collaboration might be considered a mystery in the limited sense of a puzzle or guessing game, whereby readers might seek to identify the author of any given section of a collaborative work. ${ }^{18}$ Each installment of The Whole Family teased the reader with the following invitation: "Each chapter of this novel was written by one of the twelve authors whose names appear above. The intelligent reader will experience no difficulty in determining which author wrote each chapter-perhaps" (James et al. 2001, p. xxxv). It was not until 1908 when the serialization appeared in book form that the respective authors were revealed. However, in his 1890 essay on "The Art and Mystery of Collaboration", Brander Matthews, himself one of the possible contributors to The Whole Family, ${ }^{19}$ remained skeptical of any such "effort 'to go behind the returns'" (Matthews 1901, p. 303). "Such labour," he suggested, "will be as futile as ascertaining whether a mother or father is the true parent of a child" (Matthews 1901, p. 303). Matthews advocated an alternative sense of "mystery" that privileged the "manner" of a given composition and its attendant principles: mutual esteem, respect, sympathy, tolerance and concession (he compares it to marriage) (Matthews 1901, p. 299). A collaboration amounts to simply a technical "labour-saving device" (Matthews 1901, p. 307), and the structural mastery demonstrated by French writers further distinguishes them from their English counterparts (Matthews 1901, p. 306). ${ }^{20}$

James alluded to this last sense of "mystery" in his 1879 essay on "The London Theatres": in France, "the actor's art, like the ancient arts and trades, is still something of a 'mystery' - a thing of technical secrets, of special knowledge" (James 2016, p. 237). However, for James, the mystery of collaboration was not explained by technical efficiency alone but was inseparable from a deeper paradox of unanimity. By working as a pair, the Goncourts became more, rather than less, singular: "our authors are really one in their duality" (James 1984a, p. 410). The "real wonder" was, thus, not that we got an original twice but that we got the same original twice. James made a similar point in an earlier review of Edmond de Goncourt's 1877 novel La Fille Elisa. Reflecting on the novelty that this was the first of the brothers' works to bear only one of their names on its title page (Jules de Goncourt died in 1870), James concluded that the novel's culpable "thinness" indicated that some writers achieve their own singularity only by working with others: "it seems to prove that there are some talents that need to 'collaborate,' and that they are fully themselves only on this condition" (James 1984a, p. 403). The confrères thus provided "some enlightenment (for such readers as have wondered over the matter) as to the mystery of French 'collaboration'" (James 1984a, p. 403). Unlike the verb form, print does

18 James alludes to The Whole Family project as a "game", writing to the editor Elizabeth Jordan: "I had engaged to play the game, \& take over the elements as they were \& hated to see them so helplessly muddled away when, oh, one could one's self (according to one's fatuous thought!) have made them mean something, given them sense, direction, and form" (James and Howells 1958, p. 53).

19 Bendixen notes that William Dean Howells proposed Matthews to the editor, Elizabeth Jordan, as one further contributor on 6 June $1906-$ Matthews subsequently told Jordan that he was too busy (James et al. 2001, p. xliii-xliv).

20 Brander Matthews praises the natural and instinctive "habit of collaboration which obtains in France" (Matthews 1901, p. 306), whilst the nineteenth-century critic William Walsh claims that the "modern Anglo-Saxon" is "too shy, too reticent, to unbosom himself even to a single confidant with the unreserve which collaboration calls for", hence why he claims there have not been many successful collaborations since Elizabeth I (Walsh 1909, p. 178). Robert Macfarlane also notes the clear counter examples to Walsh's claim, such as Lyrical Ballads or Frankenstein (Macfarlane 2007, p. 74). 
not discriminate between the pronunciation of the noun "collaboration" in English or in French, and the decision of voicing this invites perhaps encourages a certain cosmopolitan flexibility. James's fiction is alive to the potential drama of such choices: in The Europeans (1878), the difference between the rural environs of Boston and the soigné cosmopolitanism that interrupts it is revealed when we are told that "relations" was "one of a certain number of words that the Baroness [Eugenia] often pronounced in the French manner" (James 1878, vol. 2, p. 74). The sense that the "mystery" of collaboration derives from a perception of cultural difference was also evident in the 1878 story, "Longstaff's Marriage": Diana Belfield and her traveling companion, cousin and intimate friend Agatha Josling occupy their evenings as they conduct a European tour by keeping a "diary in common, at which they 'collaborated,' like French playwrights" and fill with quotations from Madame de Staël and Lord Byron, which they then read aloud - the "diary in common" perhaps also evokes the Goncourts' Journal (James 1879, vol. 1, p. 77).

The "mystery" of collaboration not only illuminates its complex cultural legacy but, also, helps make sense of James's continued gravitation towards a practice that was only ever partially achieved. If the Goncourts reveal the enigmas of a more widespread national practice, the formulation that "Collaboration' is always a mystery" evokes a more permanent or general condition, one which transcends cultural and historical circumstances. James's story “Collaboration" explores the universality intimated in James's account of the Goncourts, extending it beyond France and thereby deepening its affiliated mystery (by the end of the story, it remains unclear precisely how far a collaboration may extend).

\section{3. "How Had She Got Hold of It?"}

James felt that the Goncourts' Journal owed much of its steadfastness of intent to, amongst other things, "the vivid reflection of their life for twenty years, from the coup d'état which produced the Second Empire to the death of the younger brother on the eve of the war with Germany" (James 1984a, p. 412). James returned to the ramifications of this war and its persistent influence in the story "Collaboration": sacrificing his marriage to Paule de Brindes, the French poet Felix Vendemer runs away with a German musician Herman Heidenmauer to write an opera together. However, Paule's mother, Madame de Brindes, perceives Felix's collaboration as an act of disloyalty because she lost her son in the Franco-Prussian war (the slaughter of the French at Sedan in 1871). The story is thus founded on a pun: "collaboration" in the sense of joint artistic enterprise amounts to "collaboration" in the sense of betrayal. To collaborate is to collude, and the story explores the sense of betrayal at the heart of collaboration, betrayal being what loyalty lives off. However, "collaboration" also offers the chance to overcome such divisions, offering hope for a constructive, rather than exclusively destructive, kind of cooperation.

At the start of the story, Alfred Bonus, a "self-appointed emissary or agent of the great republic", wants to "prove that the Americans in Europe do get on" (James 1893, p. 104). "Getting on" is a form of collaboration that suggests both amicability and progress, continuity and advancement. However, this ambassadorial role assumes that Americans at home are more interested in the subject than they may actually be, and the narrator frequently challenges Bonus's cosmopolitan commitment: "'Come, now, do I get on?' and I sometimes push the inquiry so far as to stammer: "'And you, my dear Bonus, do you get on?'", causing him not a little injury (James 1893, p. 104). Conversation is a primary means of "getting on" and resolves these minute dramas of discrimination, as the narrator suggests: "For the conversation, I leave that mostly to take care of itself. There are discussions, of course, and differences-sometimes even a violent circulation of sense and sound; but I have a consciousness that beauty flourishes and that harmonies prevail in the end" (James 1893, p. 100). The narrator's studio, a "temple of reconciliation" (James 1893, p. 101), is the locus of this conversant exchange, whilst Paris more generally lends itself to "easy talk" and "the exchange of points of view and the comparison of accents" (James 1893, pp. 99-100). Finding the right tone might thus resolve potential discord, enabling collaboration rather than conflict. 
"Harmony" bridges the social and aesthetic senses of collaboration, and despite not having "an infallible ear", the narrator professes to knowing that music is "a universal solvent" (James 1893, p. 101), and eulogizes its restorative power: "Ah, the wounds I've known it to heal—the bridges I've known it to build—the ghosts I've known it to lay!" (James 1893, p. 101). The healing and harmonizing power of art is a notion associated with the tradition of German idealism Heidenmauer represents. In the 1794 Letters on the Aesthetic Education of Man, Friedrich Schiller conceived of art as this kind of intellectual balm capable of healing the wounds of civilization and reconciling man and nature, intellect and sense. Alluding to Kant's 1784 essay, "The Idea for a Universal History from a Cosmopolitan Point of View", Jessica Berman suggests that James's story "looks Kantian from the outset": "dramatic differences are adjudicated by the power of justice within a shared setting" (Berman 2001, p. 16), and this link between collaboration and cosmopolitanism, she concludes, is achieved through "a significant benevolence in tone, or a coming to terms after lively discussion" (Berman 2001, p. 49). Kant's account of "common sense" or sensus communis is perhaps the most famous articulation of such aesthetic universalism, a kind of "sense" that compels judgements beyond an interested report on private sensation or moral purposiveness by virtue of the objectivity ensured by universal assent.

Wagner embodies Heidenmauer's sense of collaboration as a cosmopolitan and harmonic totality: he "played Wagner, and then Wagner again-a great deal of Wagner" (James 1893, p. 128). However, James's 1889 essay-dialogue "After the Play" raised some important objections about the Wagnerian ideal. The dialogue stages a discussion between Dorriforth and Auberon; the former's position appears to be closest to James's own, whilst the latter's seeks to enact "Richard Wagner's great theory, in producing his operates at Bayreuth", by making use of "every resource of which the stage disposes" (James 2016, p. 350). For Dorriforth, the pursuit of an all-encompassing wholeness sacrifices "acting" and, consequently, enforces a separation between the dramatic and the theatrical (James 2016, p. 357). Wagner's "great theory" exemplifies this prefabricated aesthetic totality, since each artistic genre must sacrifice its own identity for the greater whole. This objection is also apparent in later criticisms of Wagner as the epitome of a kind of monumental dilettantism, seeking unity between all the arts without possessing expertise in any (Adorno 2005, pp. 18-19). For Dorriforth, false edification reveals the limits of monumental cohesion. Whilst it would indeed be "the ideal", Dorriforth says, "To have the picture complete at the same time the figures do their part in producing the particular illusion required", it is much more important, although much more difficult, to "represent a situation by the delicacy of personal art than by 'building it in'" (James 2016, p. 350). A single tone might actually be more complete than the Gesamtkunstwerk: the "imagination, in certain cases, is more finely persuaded by the little than by the much" (James 2016, p. 349), and "The face and the voice are more to the purpose than acres of painted canvas, and a touching intonation, a vivid gesture or two, than an army of supernumeraries" (James 2016, p. 350).

Whilst collaboration provides a vision of unifying harmony, "completeness" is thus by no means guaranteed by scale (similarly, in James's Roderick Hudson Preface, totality does not ensure wholeness). James's story also raises certain ambivalences regarding the status of collaboration as a redemptive reconciliation of national divisions, not least because the universalism of cosmopolitanism and its transcendence of "frontiers" and "douanes" (James 1893, p. 134) is itself depicted as a national position: Heidenmauer has "that Germanism which consists in the negation of intellectual frontiers" (James 1893, p. 106), whilst Madame de Brindes even takes "idealism" as a mark of cultural superiority rather than a transcendental given: “'Oh, German idealism-we know what that means! We've no use for their superiority; let them carry it elsewhere-let them leave us alone'" (James 1893, p. 138). If German idealism envisages art as a kind of cultural balm, for Madame de Brindes, the widow of a fallen soldier, it enacts rather than alleviates recuperated violence: "'Why do they [Germans] thrust themselves in upon us and set old wounds throbbing by their detested presence?'" (James 1893, p. 138). Cooperation can thus prove to be unexpectedly 
divisive, most obviously in the entwinement of working with and working against at the story's basis.

In the story's final scene, the question regarding whether the universality of collaboration overcomes or contributes towards national and personal divisions is presented in its most mysterious form. Paule, the tale's jeune fille, has renounced her fiancé, Vendemer, in the name of art and is seen playing one of Heidenmauer's compositions on the piano, despite having only heard it once before.

How had she got hold of it? How had she learned it? This was her secret-she blushed so that I didn't pry into it. But what is she doing, under the singular circumstances, with a composition of Herman Heidenmauer's? She never met him, she never heard him play, but that once. It will be a pretty complication if it shall appear that the young German genius made on that occasion more than one intense impression. This needn't appear, however, inasmuch as, being naturally in terror of the discovery by her mother of such an anomaly, she may count on me absolutely not to betray her. (James 1893, pp. 143-44)

The moment conjures a mystery of aesthetic provenance. The transformation is not only of Paule but of an entire generation: "doesn't the old order change?" (James 1893, p. 144), as though collaboration not only provided access to a renewed cosmopolitanism but, also, to a triumphalist supersession of outdated moralities. However, the narrator's question stands: how had Paule got hold of it? ${ }^{21}$ We might, reasonably, doubt whether Paule could reproduce Heidenmauer's after only a single hearing. Indeed, if Paule did hear the piece more than once, she might be implicated with Heidenmauer too, and this possible involvement of Paule with either of the two men provides another version of art's universal nature and its transcendence of national boundaries. This universalism is still more apparent if we accept that Paule did only hear Heidenmauer once, as though the piece made such an impression that it required no second hearing. This would reinforce the assumption that art is capable of dissolving personal factions and patriotic fidelities, contributing towards a sense of collaboration as the truest form of art itself. As Jessica Berman suggested: "the assumption is that the music (or perhaps the composer himself) has worked its charm on her and propelled her into a cosmopolitan sensibility after all" (Berman 2010, pp. 143-44). Whilst the engagement of Vendemer to a French girl provides the drama of the story and its element of discord, the tale ultimately transforms Paule from an "obstacle" into a "higher cosmopolitan understanding which she finally attains through the literal acquisition of harmony" and "becomes enlightened when she modulates her tone" (Tintner 1983, p. 50).

Just as each character in the story is, in some way, an artist ${ }^{22}$, so too is each of the main protagonists a collaborator. Even the narrator is implicated in the "pretty complication" raised by Paule's recital of Heidenmauer's piece, which we are assured is a secret safe with him and that he will not "betray". However, the depiction of the "monstrous collaboration" between Vendemer and Heidenmauer leaves it ambiguous whether the monstrosity derives from the joint venture or its actual production. "Collaboration" can refer to a continuing practice as well as a completed piece, and it remains unresolved whether the collaboration

21 James would return to a similar moment of wonder and mystery in The Tragic Muse, a story also invested in an ideal of aesthetic universalism wherein 'all art is one' and is capable of surmounting of generic boundaries (James 1890, vol. 1, p. 14). In an important scene, Peter Sherringham is shocked at Miriam Rooth's incorporation French acting within English repertory (itself a cosmopolitan success) by her reading of the scene Shakespeare's King John (II.2) when Salisbury has to tell Constance that her French king has struck a deal with John, much to her chagrin ("For I am sick and capable of fears,/Oppressed with wrongs and therefore full of fears"). Miriam's intonation enacts her transformation (she "leaped into a sudden possession of her means") and inspires Peter's question, which recalls "Collaboration": "Where did she get hold of that-where did she get hold of that?' Sherringham wondered while his whole sense vibrated. 'She hadn't got hold of it when I went away'” (James 1890, vol. 1, pp. 368-69). Madame de Carré also expresses her awe at the mysteriousness of Miriam's creativity and the origin of her genius, noting that Miriam has "'learned all I have taught you'" and asking "'where the devil have you learned what I haven't taught you?'” (James 1890, vol. 1, p. 372). For the importance of Miriam's tone in this scene, see Ricks (Ricks 1988, pp. 133-36).

22 George Bishop notes that "Vendemer is a poet, Heidenmauer a musician, Paule de Brindes 'has a happy turn for keeping a water-colour liquid', whilst her mother Madame de Brindes, employed largely in the story as the exemplar of French chauvinism, 'plies an ingenious, pathetic pen' as the authoress of 'touching tales' appearing between 'pretty lemon-coloured covers'", and even the American Bonus is described as writing to his compatriots (Bishop 1988, p. 79). 
is even worth the sacrifice, whether, for all its comprehensiveness and universality, the proposed opera will ever be "completed". If the "whole thing", as we are told, "depends on their staying power", the collaborators are running out of time: Vendemer is in a "feverish hurry, lest perhaps he should find himself chilled" (James 1893, p. 142). The final sentence confirms this open-endedness: "I shall give you some more illustrations of it yet" (James 1893, p. 142), a promissory and portentous note upon which to end a story, preserving the mystery surrounding whether such an ideal is ever even attainable.

\section{Coda}

James's contested relationship with "collaboration" need not prevent his fascination with the compositional ideal or the recognition of its frequently discernible influence upon his writing. Indeed, if James's collaborative ventures only came to limited or partial fruition, many of his protagonists would appear to show an immense aptitude for this compositional mode. In the 1909 story "Crapy Cornelia", White-Mason foregoes his marriage to participate instead in a process of imaginative reminiscence with Cornelia Rasch, in whose company he rekindles "some old community of gossip" of the old New York they share together (James 2017, p. 336). Such retrospective dialogue exceeds recovery but soon resembles a shared creative project: let us "make together, let us make over and recreate, our lost world; for which we have after all and at the worst such a lot of material" (James 2017, p. 337). In the 1910 story "A Round of Visits", James explores the absence of such collaborative retrospection: Phil Bloodgood betrays his old friend, Mark Monteith, who has recently returned to New York after a long absence. "Betrays" not only by running off with his "small peculium" or personal property but, also, by stealing "all the broken bits of the past, the loose ends of old relationships, that he supposed he might pick up again" (James 2017, p. 403). Thus Monteith's endeavor, through his round of visits, to make as "many connections" with the past as he can, such is his want of "a connection and an abutment" (James 2017, p. 403). James's Notebook entry (21 April 1884) notes his protagonist's "want of a confidant, a listening ear" (James 1987, p. 94), and, as he writes in a later entry (16 February 1899), "finding in the great heartless preoccupied city and society, every one taken up with quite other matters than the occasion for listening to him" (James 1987, p. 179). ${ }^{23}$ James's fascination with these sympathetic and creative forms of collective existence was fueled by his own return to America in 1904; entering an elevator in New York, he yearned for some relief from the "the abject collective consciousness of being pushed and pressed in", seeking collaboration rather than conflict, cohabitation rather than mere coexistence, a means of living with that still preserves the excitement of a mystery: "a dream perhaps of the thrill of fellow-feeling then taking, then finding, place-something like Robinson Crusoe's famous thrill before Friday's footprint in the sand", as he puts it in The American Scene (James 1907, p. 187).

A more extensive account of the socially unifying force of collaboration would draw on those critics sensitive to James's interest in forms of dependence that emerge from the disintegration of secure social norms (Pippin 2001) or, alternatively, on those alert to James's depiction of the universalizing ideals of ethical conduct (Nussbaum 1990). Yet James also extended collaboration beyond a social or ethical ideal into a feature of consciousness itself. In The Bostonians, the intimacy between Olive Chancellor and Verena Tarrant is imagined as a kind of joint labor: "To Olive it appeared that just this partnership of their two mindseach of them, by itself, lacking an important group of facets-made an organic whole which, for the work in hand, could not fail to be brilliantly effective" (James 1886, p. 156). In the later stories, characters frequently became either conscious or unconscious collaborators in each other's thoughts and desires. In the 1900 story "Maud Evelyn", the character of Marmaduke imaginatively enters into the mourning of the Dedricks by not only imagining he knew their daughter but that they were engaged to be married and even grew old together. "The Beast in the Jungle" gives another vision of such an imaginative alliance,

23 London (not New York) was originally the setting for this story, as indicated in the Notebooks (James 1987, p.179). 
even as it effects a disembodied intimacy: as John Marcher and May Bartram wait, watch, and grow old together, she lets "this association give shape and colour to her own existence" (James 1903b, p. 207).

Whilst James's interest in this compositional mode clearly extended beyond its literal practice, it is beyond the scope of this essay to justify a claim that the consciousness in late James is essentially collaborative. Such a claim would be confirmed by those critical accounts already sensitive to the location of thinking between, rather than within, consciousness (Cameron 1989), or to the way that many characters in late James resemble "verbal collaborators" who talk in "sentence fragments-extending and completing one another's thoughts as if they were not so much separate persons as part of a single self" (Yeazell, p. 69). This essay has limited its concern, instead, to collaboration as a specifically literary activity. What has emerged is a secret, specialized practice of elusive provenance that is, at once, of a given culture and capable of transcending it. The ineradicable enigma of collaboration compelled James's imagination, even and perhaps especially when it failed as a method of composition. The most apparently collective and universal forms of personal relation may contain elements that remain hidden or unknowable. Not all that is shared is shareable.

Funding: This research received no external funding.

Institutional Review Board Statement: Not applicable.

Informed Consent Statement: Not applicable.

Data Availability Statement: Not applicable.

Conflicts of Interest: The author declares no conflict of interest.

\section{References}

Adorno, Theodor. 2005. In Search of Wagner. Translated by Rodney Livingstone. London: Verso.

Anesko, Michael. 2012. Monopolizing the Master: Henry James and the Politics of Modern Literary Scholarship. Stanford: Stanford University Press. Berman, Jessica. 2001. Modernist Fiction: Cosmopolitanism and the Politics of Community. Cambridge: Cambridge University Press.

Berman, Jessica. 2010. Cosmopolitanism. In Henry James in Context. Edited by David McWhirter. Cambridge: Cambridge University Press, pp. 138-49.

Bishop, George. 1988. When the Master Relents: The Neglected Short Fiction of Henry James. New York: State University of New York at Buffalo.

Bradley, Frances Herbert. 1893. Appearance and Reality. Oxford: Oxford University Press.

Cameron, Sharon. 1989. Thinking in Henry James. Chicago: Chicago University Press.

Coulson, Victoria. 2007. Henry James, Women and Realism. Cambridge: Cambridge University Press.

Crane, Stephen. 1969. The University of Virginia Edition of the Works of Stephen Crane. Edited by Fredson Bowes. 10 vols. Virginia: University of Virginia Press.

Crane, Stephen. 1899. The Ghost. Play Programme Manuscript. Box 13, Stephen Crane Papers [ca.1895]-1908. New York: Columbia University Library.

Edel, Leon. 1962. Henry James: The Middle Years. Philadelphia: Lippincott.

Emerson, Ralph Waldo. 1883. 'Circles'. In Essays: First and Second Series. Boston and New York: Houghton Mifflin and Co., pp. 279-300.

Follini, Tamara. 2003. Henry James and the Spaces of "Silent-Speaking Words". Available online: https:/ / centerforhenryjamesstudies. weebly.com/uploads/3/8/1/0/38108301/follini.pdf (accessed on 18 October 2019).

Hayes, Kenneth, ed. 1996. Mr. Henry James's Novel. In Henry James: The Contemporary Reviews. Unsigned Review. Cambridge: Cambridge University Press, pp. 361-62.

Herford, Oliver. 2016. Henry James's Style of Retrospect: Late Personal Writings, 1890-1915. Oxford: Oxford University Press.

Hill, Geoffrey. 2008. Poetry as "Menace" and "Atonement". In Collected Critical Writings. Edited by Kenneth Hayes. Oxford: Oxford University Press.

Horne, Philip. 1987. Relations Will Stop at Nothing. London Review of Books, March 5. Available online: https://www.lrb.co.uk/thepaper/v09/n05/philip-horne/relations-will-stop-at-nothing (accessed on 11 January 2020).

James, Henry. 1878. The Europeans: A Sketch. London: Macmillan, vol. 2.

James, Henry. 1879. The Madonna of the Future and Other Tales. London: Macmillan, vol. 2.

James, Henry. 1886. The Bostonians: A Novel. London and New York: Macmillan.

James, Henry. 1890. The Tragic Muse. Boston: Houghton Mifflin and Co., vol. 2.

James, Henry. 1893. Collaboration. In The Wheel of Time. New York: Harper and Brothers, pp. 90-146. 
James, Henry. 1903a. The Ambassadors. New York and London: Harper and Brothers.

James, Henry. 1903b. The Beast in the Jungle. In The Better Sort. New York: Charles Scribner's Sons, pp. 189-244.

James, Henry. 1907. The American Scene. London: Chapman and Hall.

James, Henry. 1909. Italian Hours. Boston: Houghton Mifflin and Co.

James, Henry. 1913. A Small Boy and Others. New York: Charles Scribner's Sons.

James, Henry. 1914. Notes on a Son and Brother. London: Macmillan.

James, Henry. 1917. The Sense of the Past. London: William Collins Sons and Co.

James, Henry. 1920. The Letters of Henry James. Edited by Percy Lubbock. London: Macmillan, vol. 2.

James, Henry. 1984a. Literary Criticism: French Writers, Other European Writers, The Prefaces to the New York Edition. Edited by Leon Edel and Mark Wilson. New York: Library of America.

James, Henry. 1984b. Literary Criticism: Essays on Literature, American Writers, English Writers. Edited by Leon Edel and Mark Wilson. New York: Library of America.

James, Henry. 1984c. Henry James Letters. Edited by Leon Edel. Cambridge: Belknap Press of Harvard University Press, vol. 4.

James, Henry. 1987. The Complete Notebooks of Henry James. Edited by Leon Edel. Oxford: Oxford University Press.

James, Henry. 2004. Henry James on Culture. Edited by Pierre A. Walker. Lincoln: University of Nebraska Press.

James, Henry. 2006. The Complete Letters of Henry James, 1855-1872. Edited by Pierre A. Walker and Greg W. Zacharias. Lincoln: University of Nebraska Press, vol. 2.

James, Henry. 2017. Crapy Cornelia. In The Jolly Corner and Other Tales: 1903-1910. Edited by Neil Reeve. Cambridge: Cambridge University Press.

James, Henry. 2016. The Complete Writings of Henry James on Art and Drama, Volume Two: Drama. Edited by Peter Collister. Cambridge: Cambridge University Press.

James, Henry, and William Dean Howells. 1958. Henry James and William Dean Howells: A Double Billing. Novel-Writing and Novel-Reading; An Impersonal Explanation. Edited by William M. Gibson, Leon Edel and Lyall H. Powers. New York: New York Public Library.

James, Henry, William Dean Howells, Mary E. Wilkins Freeman, Mary Heaton Vorse, Mary Stewart Cutting, Elizabeth Jordan, John Kendrick Bangs, Elizabeth Stuart Phelps, Edith Wyatt, Mary Raymond Shipman Andrews, and et al. 2001. The Whole Family: A Novel by Twelve Authors. Durham and London: Duke University Press.

Johnston, Freya. 2018. Jane Austen's Universals. Essays in Criticism 68: 211-33. [CrossRef]

Jordan, Elizabeth. 1938. Three Rousing Cheers. New York and London: Appleton.

Macfarlane, Robert. 2007. Original Copy: Plagiarism and Originality in Nineteenth-Century Literature. Oxford: Oxford University Press.

Matthews, Brander. 1901. The Art and Mystery of Collaboration. In The Historical Novel, and Other Essays. New York: Charles Scribner's Sons, pp. 295-321.

McWhirter, David. 1995. 'Introduction'. In Henry James's New York Edition: The Construction of Authorship. Edited by David McWhirter. California: Stanford University Press.

Millgate, Michael. 1992. Testamentary Acts: Browning, Tennyson, James, Hardy. Oxford: Oxford University Press.

Nussbaum, Martha. 1990. Love's Knowledge. Oxford: Oxford University Press.

Perosa, Sergio. 1978. Henry James and the Experimental Novel. Virginia: University of Virginia Press.

Pippin, Robert. 2001. Henry James and Modern Moral Life. Cambridge: Cambridge University Press.

Ricks, Christopher. 1988. T.S. Eliot and Prejudice. Berkeley: University of California.

Tintner, Adeline. 1983. Rudyard Kipling and Wolcott Balestier's Literary Collaboration: A Possible Source for James's "Collaboration". The Henry James Review 4: 140-43. [CrossRef]

Walsh, William. 1909. Handy-Book of Literary Curiosities. Philadelphia: Lippincott.

Wilson, Ross. 2017. Henry James at Any Rate. The Henry James Review 38: 250-59. [CrossRef]

Wordsworth, William. 2008. The Major Works, rev. ed. Edited by Stephen Gill. Oxford: Oxford University Press.

Yeazell, Ruth Bernard. Language and Knowledge in the Late Novels of Henry James. Chicago: Chicago University Press. 